\title{
A MULTIYEAR QUALITATIVE STUDY OF AN ISOLATED INLAND POPULATION OF SALT HELIOTROPE (HELIOTROPIUM CURASSAVICUM VAR. CURASSAVICUM, BORAGINACEAE) IN ARKANSAS, U.S.A. \\ Renn Tumlison \& Brett Serviss
}

Department of Biological Sciences
Henderson State University
Arkadelphia, Arkansas 71999, U.S.A.

ABSTRACT

In Arkansas, Heliotropium curassavicum L. (salt heliotrope, seaside heliotrope) is known from only three locations in which higher salinity allows its existence. We examined one of these sites along Saline Bayou, Clark County, over a period of 10 years to examine the life history of one variety of the species, H. curassavicum L. var. curassavicum (salt heliotrope) in a patch habitat. Seedlings were found only where other plant species did not grow and in areas of soil activity (caused by salinity) much higher than sites upstream of a salt seep. Flood events scoured the streambed habitat, often uprooting established plants, but yearly recruitment was observed from dispersed seeds. Impoundment by beavers (Castor canadensis) more permanently flooded a section of the habitat, resulting in no growth of the plant in newly inundated spaces, but greater numbers of new sprouts were observed along the new banks in the salty portion of the stream. Shading seemed to limit growth of the heliotrope along the stream and under a bridge, as few plants sprouted in those areas and any that did were stunted compared to other specimens growing in full sun.

\section{RESUMEN}

En Arkansas, Heliotropium curassavicum L. (heliótropo de sal, o heliótropo de costa) se conoce solo de tres localidades en las que la alta salinidad permite su existencia. Se estudió uno de estos lugares a lo largo de Saline Bayou, Clark County, durante un periodo de 10 años para examinar la historia de la vida de una variedad de la especie, H. curassavicum L. var. curassavicum (heliótropo de sal) en una parcela del hábitat. Se encontraron plántulas solo donde otras especies de plantas no crecían y en áreas de actividad del suelo (causada por salinidad) mucho más alta que en lugares aguas arriba de una filtración de sal. Los eventos de inundación limpian los hábitats de cauces, desarraigando a menudo las plantas establecidas, pero se observó reclutamiento anual a partir de las semillas dispersadas. El embalsamiento por castores (Castor canadensis) inundaba de modo más permanente una sección del hábitat, dando como resultado que la planta no crecía en los espacios inundados recientemente, pero se observó mayor número de nuevas plántulas a lo largo de nuevos bancos en la porción salada del cauce. La sombra no pareció limitar el crecimiento del heliótropo a lo largo del cauce y bajo un puente, ya que en estas áreas brotaban pocas plantas y las que lo hacían eran diminutas comparadas con otros especímenes que crecían a pleno sol.

\section{INTRODUCTION}

As shallow seas receded during the Tertiary period, salts were deposited and covered by sediments at several locations in modern southern Arkansas. Underground water rising through these deposits surfaced to create salt springs in parts of Saline Bayou in modern Clark County, Arkansas, with enough salt that the original people (Caddo) were making salt there $~ 800$ years ago (Rose 1952) and European peoples developed salt industry there in around 1812 and 1860 (Littlefield 1973). Seepage of salt continues, resulting in saline soils essentially bare of vegetation except for scattered plants of Heliotropium curassavicum L. var. curassavicum (salt heliotrope).

Heliotropium curassavicum is a small, succulent, prostrate to decumbent annual or short-lived perennial from a rhizomatous rootstalk (Correll \& Correll 1975; Godfrey \& Wooten 1981). It can be weedy and is found generally in alkaline or highly saline soils (often in coastal areas) under both dry and wet conditions (Correll \& Correll 1975; Godfrey \& Wooten 1981). It is generally considered native to the New World from the southern United States through Central America, and from the West Indies into South America (Correll \& Johnston 1970). However, it also is naturalized in other areas of the world, including Australia (possibly also native there) and Europe (Correll \& Correll 1975; Hussey et al. 1997). The fruits and seeds of H. curassavicum possess a thick-layered, vesicular exocarp, which acts as a float-organ in water dissemination of the seeds (Correll \& Correll 1975). Although there are three varieties of H. curassavicum present in the U.S. flora, only variety 
curassavicum is currently documented from southwestern Arkansas (Arkansas Vascular Flora Committee 2006; Tumlison \& Serviss 2007).

Only three records of $H$. curassavicum currently are known from Arkansas, including the population of $H$. curassavicum L. var. curassavicum discovered on a sandy bar adjacent to old salt-making works in Saline Bayou, Clark County, Arkansas (Tumlison \& Serviss 2007; Gentry et al. 2013), which is the subject of this 10-year study. The salt-processing site was populated by few plants other than scattered individuals of salt heliotrope, and crusts of salt were apparent on rocks and sand in the immediate area. A few of these heliotrope plants occurred as far as $100 \mathrm{~m}$ downstream at the time of discovery. Due to the very limited range based on the specialized salty habitat, and the yearly significant alterations to the environment effected by seasonal flooding of the stream, we studied the species over a 10-year period to examine how the population responded to environmental fluctuation and change to which it was subjected.

\section{METHODS}

Study site.-The study site was located in the lower portion of Saline Bayou, which feeds into the Ouachita River in Clark County, Arkansas, and is accessed via the bridge for AR St. Hwy 7. Salt heliotropes were found only occasionally at sites downstream of the bridge, which were mostly shaded. A saline seep was present on the south bank of the stream just downstream of the bridge. Salt heliotrope plants occurred commonly where exposed to sun on either side of the bridge. Upstream from the bridge, the bed curved to the left and included a gravelly side bed that remained moist but had no pool except with higher water; this area had canopy closure. Further upstream, the bed widened, had a mild bed slope that retained a shallow pool, and was exposed to sun on the north bank but was shaded on the south bank. The historic salt works occurred on the north bank at the most upstream part of this pool. A very small feeder drainage ran north from just below the salt works. This salt work area sustained the most plants and consistently produced plants all years of the study. Length of the stream between the most extreme points we ever found salt heliotropes was about $0.25 \mathrm{~km}$.

We began study of the Clark County salt heliotrope population in 2007, soon after its original discovery (Tumlison \& Serviss 2007), and followed the yearly cycle through 2017. To evaluate the ecology and distribution of this population, we studied the site during a total of 50 trips. We determined the distribution of heliotrope plants each year and followed their chronology from emergence through set of seed and disappearance. We examined effects of temporary flooding due to rainfall, more permanent flooding due to impounding activity by beavers (Castor canadensis), effects of other wildlife, and effects of shading. Voucher specimens of salt heliotrope from the Clark County location were collected in 2006 (Serviss 7095), 2007 (Serviss 7266), and 2012 (Serviss 7571, Serviss 7764), and were deposited in the Henderson State University Herbarium (HEND).

Salt heliotrope germinated with its widest distribution during 2012. Thus, we expected that the most variation in soil salinity at the location of a plant would be represented at this time. During 2012, we used a Hanna Instruments HI 993310 Soil Activity Meter to examine soil activity (a reflection of salinity). This instrument does not measure exact concentrations of salinity, and has no specific units of measure or a conversion factor to estimate salinity. We used this device because it allowed rapid collection of data that could be used to compare numerous sites on the same day. We obtained readings at specific locations growing salt heliotrope plants and compared those readings with values determined in similar soils upstream from the study site, but which never produced specimens of this plant.

Further, we obtained soil activity readings at the specific location of individual plants on 27 Jun, 11 Aug, and 10 Oct to assess the degree to which seasonal change in water levels might affect activity of the soil that supported this species. We used the Student's t-test to compare soil activities on different dates.

\section{RESULTS AND DISCUSSION}

We anticipated that a long-term study would allow examination and comparisons of the salt heliotrope population under different environmental conditions, essentially following a natural experiment. In 2007, the study area was largely open with moderate streambed vegetation along banks and on sand bars, with the exception 
of an area around the salt works and the north bank just downstream. By 2017, the area was muddy from deposition of sediments, and vegetation along banks and mud bars was thick, with the same exception already noted. Near the end of the 2007 study season, beavers moved in and constructed dams. Beaver dams were damaged or destroyed by floods and rebuilt through the period of study. Activity of beavers had its greatest influence on habitat during 2008, 2012, 2014, and 2015. By damaging beaver dams, flooding reduced the effects of impoundment and was an important determinant of habitat structure in 2008, 2009, and 2013. Streambed scour due to heavier rainfall occurred to various degrees and at different times each year. Droughts reduced water level and most influenced habitat during 2010 and 2011.

Emergence of seedlings, as well as the disappearance of plants, apparently depended on temperature and water level each year. Inundation of usual germination sites delayed sprouting, flooding events scoured the substrate and removed plants, and surface portions of plants died with the first hard freeze.

Salt heliotrope seedlings grew almost exclusively in a zone in which no other plants would grow, presumably due to the salinity of the substrate (Correll \& Correll 1975; Godfrey \& Wooten 1981). With warm springtime conditions and moderate water levels, seedlings appeared as early as March. When springtime rains swelled the stream, seedlings were found sprouting only after water levels returned to normal. New seedlings continued to appear throughout the season until October each year, so while some plants had progressed to setting fruit, new plants were constantly being added to the population. This resulted in protection of the population from extirpation by a single flood, because new seed had already been produced if a flood happened later in the year, and new plants sprouted and had time to mature if a flood occurred earlier in the season.

Seedlings appeared along portions of the streambank, or in groups along the tails of sand bars, that were kept moist by proximity to water but were not submerged. For example, in Apr 2010, hundreds of sprouting salt heliotropes appeared in the area of the historic salt works in a zone visibly defined as the wet/dry interface. In contrast, the spring of 2011 was very dry, and by 27 Jun, well after normal germination, we still had not located seedlings in this same area, but did note very low water levels and cracked, dry soil in the usual sprouting zones. Lack of seedlings appeared to be related to lack of moisture at that time, but seedlings appeared when presence of water restored the zone to moist conditions. Germination in all other years also was in damp soils as described.

Often, we encountered tight clusters of seedlings. Turbulent flow from seasonal rains scattered fruits/ seeds, but also buried infructescences in sediments. If conditions for germination developed, seeds germinated as a group from the infructescence (Fig. 1).

Blooming occurred as early as 9 Apr and continued through mid-Nov (i.e., the first frost). The flowering season in our study included plants in various stages of reproductive and vegetative development throughout the spring, summer, and fall. Plants would begin to bloom with only one major stalk possessing an inflorescence, but plants (or clusters of them) that bloomed early in the season and survived the summer developed multiple stalks and inflorescences and sometimes extended over $1 \mathrm{~m}$ in breadth.

Fruit development began by late May, and plants with attached fruits were present as late as Dec unless they had been removed by scour of the streambed after heavy rains. Plants that survived from the spring developed long strands of fruits and were shedding some of them while others were maturing, so seeds were available for dispersion with any summertime rain.

Effects of soil activity (salinity). - Soil activities were recorded at the immediate location of salt heliotropes over three dates during the growing season of 2012 to evaluate possible changes during the period. The season began drier than normal in May with encrustations of salt appearing on sand and stones, but few salt heliotropes had sprouted, likely due to low water. Soil activity was tested on $27 \mathrm{Jun}$, after rains had refilled the channel of the stream and numerous salt heliotropes had germinated. On 11 Aug, salt heliotropes had established and water had receded, again leaving visible salt deposits on sand and stones. Fall rains had swept away surface salt by the 10 Oct salinity measurements.

Interestingly, activities over the three dates were very similar (Table 1 ) and were not statistically different 


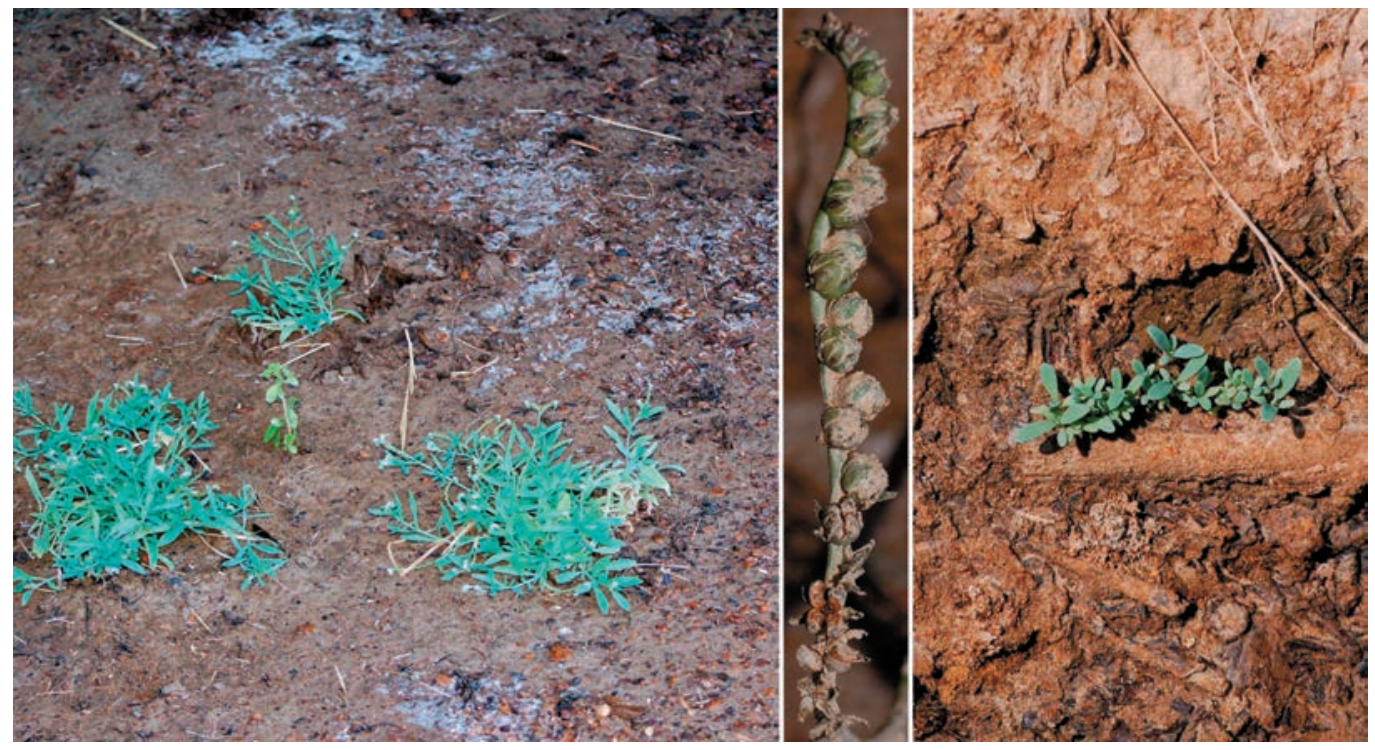

FIG. 1. Heliotropium curassavicum L. var. curassavicum at Saline Bayou, Clark Co., Arkansas. Left, three salt heliotrope plants in otherwise bare habitat along the bank of the stream (note white patches of crystallized salt). Middle, infructescence. These are often buried during sedimentation during higher streamflow. Right, a group of seedlings that germinated from a buried infructescence.

between any dates (27 Jun and 11 Aug, $t=1.34, \mathrm{df}=146, P<0.05 ; 11$ Aug and $10 \mathrm{Oct}, t=1.05, \mathrm{df}=164, P<0.05$; 27 Jun and 10 Oct, $t=0.42, \mathrm{df}=80, P<0.05)$. Although stream flow removed surface salt, the upward seepage of salty water from beneath the stream bed apparently maintained essentially constant soil salinities. Even summertime drying of the streambed increased soil activity only slightly. Apparently, accumulating salt in the soil was wicked to the surface and reduced by becoming encrusted on the surface, and rains swept it away. Given that activity of the subsurface soil in the immediate area of the salt works seems to be relatively constant and appropriate for success of these salt heliotropes, and gives them a competitive edge over stenohaline species, the unique habitat matches habitat requirements for this plant.

Overall soil activity values at sites growing salt heliotrope averaged $1.33(\mathrm{n}=198, \mathrm{SD}=0.28$, range 0.57 1.86). Soils at sites upstream of the salt works, at which the habitat visibly appeared to be the same but grew other plants and never germinated salt heliotrope, averaged soil activities of 0.43 ( $n=16, S D=0.22$, range $0.22-0.95)$. These differences were highly significant $(t=12.25, \mathrm{df}=211, P<0.0001)$. This analysis explains our field observations that these plants are adapted to saline soils in which other inland species of plants generally cannot grow. Salt heliotrope grows in soil salinity levels up to $16 \mathrm{dS} / \mathrm{m}(=\mathrm{mS} / \mathrm{cm}$; Weber $\&$ Hanks 2006), but higher salinity levels have been demonstrated to reduce seed germination in salt heliotrope (Dhankhar et al. 2002).

On 10 Oct 2012, plants that sprouted earlier in the year had their longest time to develop. We observed that the five largest plants (those spreading $0.5 \mathrm{~m}$ or more) were found in areas with full exposure to the sun and grew in areas with soil activities of 1.25 or higher (see methods).

Effects of flooding.- Spring rains and summer thunderstorms inundated the study area with swift currents for a few days almost every year. Resulting scouring of the streambed and rearrangement of sediments uprooted even the most established salt heliotrope plants within the affected basin. However, these events also apparently distributed seeds to various shoreline elevations as water level rose and dropped. This outcome was evidenced by the variable location of some patches of seedlings each year. Because plants grew at various elevations up the vertical streambank, some individuals usually escaped the effects of scour and provided seeds for 
TABLE 1. Soil activities at specific locations of growing plants in habitat of Heliotropium curassavicum L. var. curassivicum during three dates at Saline Bayou, Clark County, Arkansas, during 2012.

\begin{tabular}{llllll}
\hline Date & $\mathbf{n}$ & Mean & Minimum & Maximum & SD \\
\hline 27 June & 32 & 1.28 & 0.72 & 1.80 & 0.32 \\
11 August & 116 & 1.35 & 0.57 & 1.86 & 0.29 \\
10 October & 50 & 1.30 & 0.70 & 1.79 & 0.28 \\
\hline
\end{tabular}

the next season. This was particularly true at the elevated site of the old salt works, where consistent production of plants every year indicated this site may serve as a refugium against poorer years of plant survival and seed production. In 2014 and 2015, we even located salt heliotropes sprouting from seeds deposited $30 \mathrm{~m}$ up the feeder drainage, presumably from the eddy effects seen at the site during high water.

An example of high-water effects occurred at the salt works during Sep 2007. Part of an elevated bank supporting salt heliotropes caved into the water, but a more elevated patch of plants just a few meters away remained untouched and produced seed. All but a few of the formerly numerous seedlings along the banks of a pool area were scoured away, as well as a group of small plants growing in a shallow depression just off of the main stream bed.

Repetitive high water and streambed scour from Apr through early Jul of 2008 left the area with only a few scattered plants, but on $30 \mathrm{Jul}$, new germination and growth had produced 125 plants ranging from seedlings to flowering individuals. These developed and produced seed until early Sep, when up to $23 \mathrm{~cm}$ of rain from remnants of Hurricane Gustav scoured the streambed (Clark County was considered a disaster area (FEMA1793-DR, Arkansas Disaster Declaration 2008)). Afterward, only one small salt heliotrope plant was found. However, the next year (2 Jul 2009) we noted an abundance of salt heliotropes ranging from seedlings to small non-flowering plants at many locations, but none was present on a trip on 13 Aug 2009. They had been scoured away by the heavy rains of Jul $(36.5 \mathrm{~cm}$ compared to the normal $11.7 \mathrm{~cm}$ (U.S. Climate Data 2018). The same floods that scoured out most of the population of salt heliotropes also scattered their seeds to produce plants for the next generation, which promoted continued survival of the species within the very limited suitable habitat.

Each year, seedlings sprouted in areas defined by a combination of salt seepage, presence of moisture without inundation, and full sunlight. These conditions were met at various elevations within the general streambed in different years. Most locations of germination were consistent among years, but new locations were found throughout the study period that matched high-water levels of the previous year, or locations where new sand bars had been formed. For example, on 29 Apr 2010, four years into the study, we first discovered seedlings sprouting at a higher elevation up a roadside drainage ditch that emptied at the bridge near the lower end of the study site, and by 28 May these plants were blooming. In the following months rains removed plants at lower elevations whereas those in the ditch escaped the scouring and continued to grow, trailing into the creek bed with numerous long infructescences until December.

Effects of beaver and other wildlife.-Effects of flooding scour the lentic environment, but impoundment has the opposite effect. The study site had been visited for several years prior to the beginning of this study, and beaver activity had not been observed. However, in late Aug 2007, beaver settled into the area and created three dams which raised water levels and caused death of the salt heliotropes submerged by the ponds. The following year, numerous seedlings appeared along the edge of the largest beaver pond. That area had a gradual slope and the seeds were either dispersed along the edge of the water, or only germinated there. The thick-layered, vesicular exocarp of fruits and seeds of H. curassavicum are known to aid in water dispersion of the seeds (Correll \& Correll 1975).

The area covered by impounded water did not grow any salt heliotrope. Formation of the beaver pond may have stabilized the moisture level across this gradual slope and aided in increased germination along the shoreline, as many more plants were found along the edge of the beaver pond than had been found in the same 
area without the pond. Heavy rains and their scouring effect still removed plants, but more germinated along the edge of the pond than had previously.

Over the period of study, dams were broken by high waters and eventually rebuilt several times, but remnants of dams always maintained reduced pools. After initial construction of dams, we observed salt heliotrope growing up the feeder drainage by the salt works. This may be because local moisture content was raised and provided conditions for germination, or because the ponding effect created eddies in higher waters (which we witnessed during high water), and let salt heliotrope seeds be dispersed up the feeder stream, where conditions were suitable for germination. Propagule dispersal mechanisms determine compositional trends of macrophytes in beaver ponds (Ray et al. 2001).

Through their activities, beaver act as a keystone species that alters hydrology and geomorphology (Naiman et al. 1986), and beaver ponds allow sedimentation at much higher rates than unimpounded streams (Kroes \& Bason 2015). Up to the beginning of this study, the substrate of the stream in the study area was largely sandy to gravelly with a thin coat of mud and with several moderately to sparsely vegetated sand/mud bars. Toward the end of the study, dams of beavers had changed flow dynamics allowing considerable buildup of sediments and thick packs of mud and bars composed mostly of mud.

Accumulation of sediment is attended by accumulation of organic matter (Naiman et al. 1994; Ray et al. 2001), and faunal and plant community structure is modified (Brzyski \& Schulte 2009). These effects were very noticeable in the last three years of the study. Vegetation associated with the salt heliotrope when it was first discovered at the site (Tumlison \& Serviss 2007) included Zizaniopsis miliacea (southern wild rice), but the plants were far less common before the beaver established dams. By 2017, this plant dominated much of the area and stabilized the mud bars, which seems to have made them unsuitable habitat for the salt heliotrope (evidenced by lack of germination on bars that did support salt heliotrope plants prior to establishment of southern wild rice). Southern wild rice is known to exclude a number of other plant species (Steenis \& Cottam 1945; Penfund 1952; Martin 1953; Holmes \& Stalling 1990), sometimes occurring in dense, nearly impenetrable, essentially monospecific stands.

Alteration of habitat brought about by stream impoundment by beavers also affects populations of amphibians, brought about by favorable changes from lentic to lotic habitats (Metts et al. 2001; Stevens et al. 2006). Throughout the study, the only species of amphibian commonly seen was the cricket frog (Acris blanchardi). This species is tolerant of salinity compared to other frogs (Hua \& Pierce 2013). However, in Sep 2017, dozens of young green treefrogs (Hyla cinerea) were hiding in the leaves of Zizaniopsis miliacea, though we had only occasionally seen this frog in the area during the first years of our study. General habitat for this frog is vegetated areas near permanent water (Trauth et al. 2004), and it is a freshwater species more tolerant of saline waters than most inland amphibians (Brown \& Walls 2013). Our observed change in herpetofauna reflects some changes in habitat that may be adversely affecting salt heliotropes.

Physical activity by beavers also had a small impact on plants at specific sites. Beavers used some slopes along the bank as slides and eroded any plants at the site; however, this impact appeared to be minimal. Feral hogs (Sus scrofa) foraging along banks near the site uprooted vegetation, but they did not appear to have significantly affected specific sites with salt heliotropes.

Of 23 plants we had marked on 17 Apr 2007, 11 had been browsed by white-tailed deer (Odocoileus virginianus) and six others were gone (possibly browsed) on 25 May. Several larger plants that were well-developed and flowering on 28 Jun 2010 were severely cropped from browsing on 31 Jul, but they were re-growing. Browsed plants also were re-growing on 11 Aug 2012 and 10 Oct 2012. We observed that browsing by deer had only short-term and minimal overall negative effects on the salt heliotrope population.

Effects of shading.-We evaluated effects of shading by comparing locations of growth and absence, and of development where plants were found. At the bridge, plants were found on either side where shade was minimal. Very few salt heliotropes grew underneath the bridge, and those that did tended to not reach a flowering stage, although those growing just away from the bridge sometimes spread up to a meter in width and had multiple infructescences. Further, shaded plants tended to yellow and wilt during all years. 
Near the salt works, salt heliotropes consistently grew every year only on the sunny (north) bank. On 11 Aug 2012, we found salt heliotrope on the shaded (south) bank, which was the only observation of those plants at this location during the study period. The plants were small, single-stemmed, and a few were flowering. Adequate moisture was present for germination, so we tested soil activity along the south bank. Average activity was consistent with activities required for these plants at other sites $(n=16$, mean $=1.35$, range 0.96$1.72, \mathrm{SD}=0.23$; compare with Table 1). Because moisture and salinity were appropriate for growth, and germination demonstrated that seeds dispersed to the area, the typical annual lack of plants (or poorer development when they did germinate) appeared to be related to the minimal sunlight on that bank.

Finally, salt heliotropes also sprouted yearly in the shaded gravelly side channel to the main stream. Water did not pool in the area except after rains, but saline seeps kept the area moist. Some years these plants were scoured away with heavy rains, but even in drought years they did not grow very large. Near complete canopy closure in that area likely limited growth, much as it did under the bridge. Other plants observed on 10 Oct 2012 in shadier areas were small and appeared stunted.

\section{ACKNOWLEDGMENTS}

We thank Mark Karnes and the Ross Foundation, Arkadelphia, Arkansas, for access to the study site. We also thank the Henderson State University Department of Biological Sciences and the Ellis College of Arts and Sciences for supporting this work. We thank two anonymous reviewers for their constructive comments.

\section{REFERENCES}

Arkansas Vascular Flora Committee. 2006. Checklist of the vascular plants of Arkansas. Arkansas Vascular Flora Committee, University of Arkansas, Fayetteville, Arkansas, U.S.A.

BRown, M.E. \& S.C. WALLS. 2013. Variation in salinity tolerance among larval anurans: Implications for community composition and the spread of an invasive, non-native species. Copeia 2013:543-551.

BRZYSKI, J.R. \& B.A. Schulte. 2009. Beaver (Castor canadensis) impacts on herbaceous and woody vegetation in southeastern Georgia. Amer. Midl. Naturalist 162:74-86.

CorrelL, D.S. \& H.B. Correlt. 1975. Aquatic and wetland plants of the southeastern United States, Volume II. Stanford University Press, Stanford, California, U.S.A. Pp. 1384-1387.

CoRRELL, D.S. \& M.C. Johnston. 1970. Manual of the vascular plants of Texas. Texas Research Foundation, Renner, Texas, U.S.A.

DhANKHAR, R., A. KaushiK, \& J.S. DahIYA. 2002. Germination responses and biomass accumulation of three native plant species of Haryana, India under salinity stress. Pl. Arch. 2:263-267.

FEMA-1793-DR, Arkansas Disaster Declaration. 2008. Available at www.fema.gov/disaster/1793. Accessed Jan 2018.

Gentry, J.L., G.P. Johnson, B.T. BAKER, C.T. WiTSELL, \& J.D. OgLE, EDS. 2013. Atlas of the vascular plants of Arkansas. Univ. of Arkansas Herbarium, Fayetteville, Arkansas, U.S.A.

GodfreY, R.K. \& J.W. Wooten. 1981. Aquatic and wetland plants of the southeastern United States, Dicotyledons. The University of Georgia Press, Athens, Georgia, U.S.A.

Holmes, W.C. \& D.T. STaluing. 1990. Studies on the reproductive strategy of Zizaniopsis miliacea (Michx.) Doell. \& Asch. (Gramineae:Tribe Oryzeae). Castanea 55:113-121.

HuA, J. \& B.A. PierCE. 2013. Lethal and sublethal effects of salinity on three common Texas amphibians. Copeia 2013:562-566.

Hussey, B.M.J., G.J. KelGBerY, R.D. Cousens, J. DodD, \& S.G. Lloyd. 1997. Western weeds: A guide to the western weeds of Australia. The Plant Protection Society of Western Australia (Inc.), Victoria Park, Western Australia. Pp. 110-112.

KRoEs, D.E. \& C.W. BAson. 2015. Sediment-trapping by beaver ponds in streams of the mid-Atlantic Piedmont and Coastal Plain, USA. S. E. Naturalist (Steuben) 14:577-595.

LITTLEFIELD, D.F., JR. 1973. The salt industry in Arkansas Territory, 1819-1836. Arkansas Hist. Quart. 32:312-336.

MARTIN, A.C. 1953. Improving duck marshes by weed control. U.S. Department of the Interior, Fish and Wildlife Service Circular No. 19. U.S. Government Printing Office, Washington, D.C., U.S.A.

MetTS, B.S., J.D. LANHAM, \& K.R. RusSELL. 2001. Evaluation of herpetofaunal communities on upland streams and beaverimpounded streams in the upper Piedmont of South Carolina. Amer. Midl. Naturalist 145:54-65. 
Naiman, R.J., J.M. Melillo, \& J.E. Hobbie. 1986. Ecosystem alteration of boreal forest streams by beaver (Castor canadensis). Ecology 67:1254-1269.

Naiman, R.J., G. PinaY, C.A. Johnston, \& J. PAStoR. 1994. Beaver influences on the long-term biogeochemical characteristics of boreal forest drainage network. Ecology 75:905-921.

Penfund, W.T. 1952. Southern swamps and marshes. Bot. Rev. 18:413-446.

Ray, A M., A.J. Rebertus, \& H.L. Ray. 2001. Macrophyte succession in Minnesota beaver ponds. Canad. J. Bot. 79:487-499. Rose, F.P. 1952. Primitive salt works. Arkansas Hist. Quart. 11:315-326.

SteEnIS, J.H. \& C. Cottam. 1945. A progress report on the marsh and aquatic plant problem: Reelfoot Lake. J. Tenn. Acad. Sci. 20:6-19.

Stevens, C.E., C.A. PAszkowski, \& G.J. Scrimgeour. 2006. Older is better: Beaver ponds on boreal streams as breeding habitat for the wood frog. J. Wildl. Managem. 70:1360-1371.

Trauth, S.E., H.W. Robison, \& M.V. Plummer. 2004. The amphibians and reptiles of Arkansas. University of Arkansas Press, Fayetteville, Arkansas, U.S.A.

Tumlison, R. \& B.E. SeRviss. 2007. Discovery of a second record of seaside heliotrope (Heliotropium curassavicum L.) (Boraginaceae) in Arkansas. J. Arkansas Acad. Sci. 61:137-139.

U.S. Climate DatA. 2018. Available at www.usclimatedata.com. Accessed Jan 2018.

WeBeR, D.J. \& J. HANKs. 2006. Heliotropium currasavicum. In: M.A. Khan \& D.J. Weber, eds. Ecophysiology of high salinity tolerant plants. Springer Press, Netherlands. 